\title{
IMPLEMENTASI DAN EFEKTIFITAS MOBILE LEARNING DENGAN MENGGUNAKAN METODE SYNCHRONOUS DAN ASYNCHRONOUS LEARNING PADA PEMBELAJARAN BAHASA INGGRIS DI UNIVERSITAS KUNINGAN BERBASIS ANDROID
}

\author{
Panji Novantara, M.T*1, Heri Herwanto, M.Pd ${ }^{2}$ \\ ${ }^{1}$ Manajemen Informatika Universitas Kuningan \\ ${ }^{2}$ Sistem Informasi Universitas Kuningan \\ Jl Cut Nyak Dien No 36 A Cijoho Kabupaten Kuningan \\ "1Panji@uniku.ac.id, ${ }^{2}$ Heri@uniku.ac.id
}

\begin{abstract}
Abstrak
Penelitian ini dibuat bertujuan untuk mengimplementasikan dan mengukur efektivitas media pembelajaran melalui mobile learning dengan menggunakan metode Synchronous dan Asynchronous Learning berbasis android untuk mata kuliah Bahasa Inggris kepada mahasiswa di universitas Kuningan.Target penelitian yang ingin dicapai adalah adanya media belajar tambahan yang menarik dan mudah digunakan sehingga dapat meningkatkan minat belajar dan prestasi mahasiswa dalam mata kuliahBahasa Inggris.Penelitian ini akan membahas bagaimana merancang, mengembangkan juga mengevaluasi efektifitas penggunakan aplikasi Mobile Learning berbasis Android untuk mata kuliahBahasa Inggris di kalangan mahasiswa Universitas Kuningan dengan metode Synchronous dan Asynchronous Learning. Aplikasi ini dibuat supaya pengguna dapat secara mudah mengakses suatu materi kuliah Bahasa Inggris menggunakan aplikasi Mobile Learning melalui Smartphone.Aplikasi Mobile Learning ini merupakan aplikasi media pembelajaran alternatif berbasis Android yang berdiri sendiri dan dapat diimplementasikan pada Smartphone berbasis Android.
\end{abstract}

Kata Kunci: Mobile Learning, Bahasa Inggris , Synchronous Learning, Asynchronous Learning, Media pembelajaran. 


\section{PENDAHULUAN}

Pemanfaatan mobile juga sudah dapat dirasakan didalam proses pembelajaran. Pemanfaatan teknologi informasi sebagai media pembelajaran dalam dunia pendidikan sudah mulai digunakan di kampus-kampus, termasuk di Universitas Kuningan. Sebagaimana seorang pengajar di suatu kampus, Teknologi mobile dapat digunakan sebagai media dalam proses belajar mengajar yang mempunyai fungsi sebagai media tutorial, alat peraga dan alat uji sehingga akan sangat membantu dalam proses penyampaian dan pemahaman terhadap materi kepada mahasiswa dimana saja dan kapan saja.

Salah satu mata kuliah yang ada di kampus dan harus diajarkan kepada mahasiswa diantaranya adalah mata kuliah bahasa Inggris. Dalam proses pembelajaran Bahasa Inggris, banyak pengajar yang belum memaksimalkan dalam memanfaatkan penggunaan media pembelajaran berbasis mobile learning melalui M-Learning.

$\begin{array}{rrrr}\text { Untuk } & \text { melengkapi } & \text { sarana penunjang } \\ \text { pembelajaran } & \text { Bahasa } & \text { Inggris maka } \\ \text { dirancanglah } & \text { media } & \text { pembelajaran }\end{array}$ menggunakan komputer dan internet yang berbasis mobile disebut dengan M-Learning. M-learning didefinisikan sebagai sebuah metode pembelajaran dan pengajaran yang menggunakan media elektronik (terkoneksi dengan sambungan Internet) untuk menyampaikan materi dan bimbingan berbasis Mobile. Ada juga yang memberikan definisi $M$ learning sebagai bentuk pembelajaran jarak jauh yang dilakukan melalui media internet. $M$ learning memberikan kemudahan kepada pengguna untuk mendapatkan banyak materi dari Internet serta berbasis mobile.

Teknologi M-learning masih memiliki kekurangan yaitu kurang optimalnyanya kemampuan fitur dan layanan m-learning dalam memberikan pembelajaran kepada pengguna, hal ini dikarenakan masih banyak kelebihan dan kemampuan lain yang dapat dioptimalkan dari penggunaan m-learning.

Sebagai solusi untuk mengembangkan kemampuan dari M-learning maka dikembangkanlah metode pembelajaran sebagai teknik penyampaian pembelajaran melalui $\mathrm{M}$ learning dengan menggunakan metode Synchronous and Asynchronous Learning . Aplikasi Mobile Learning harus dirancang secara lebih efektif, efisien dan optimal dibandingkan dengan aplikasi yang dirancang untuk E-learning.
Berdasarkan latar belakang di atas, maka penulis berinisiatif membuat suatu aplikasi Mobile Learning dengan menggunakan metode Synchronous and Asynchronous Learningyang menarik dan dapat digunakan sebagai media belajar pelengkap mahasiswa di kampus. Dengan adanya aplikasi ini diharapkan dapat menarik minat mahasiswa untuk belajar Bahasa Inggris dan dapat meningkatkan prestasi belajar mahasiswa dalam mata kuliah Bahasa Inggris. Dengan adanya aplikasi ini juga diharapkan dapat memberi manfaat dan pengetahuan bagi mahasiswa tentang pembelajaran bahasa Inggris lebih dalam dan jelas.

\section{METODE PENELITIAN}

\section{a. Konsep M-Learning}

Saat ini multimedia telah memasuki bisnis dan dunia pendidkan seiring dengan perkembangan teknologi komunikasi yang berkembang pesat, bahkan multimedia komputer sudah menjadi standar pembelajaran baru didalam dunia pendidikan yanglebih menarik dan interaktif. Multimedia menurut etimologinya berasal dari kata multi yang berarti banyak dan dari kata media yang berarti sarana komunikasi untuk memberikan informasi. Multimedia juga merupakan suatu sistem yang terdiri dari perangkat keras, perangkat lunak dan alat-alat lain seperti : televisi, monitor, video, dan sistem piringan optik yang dimaksudkan untuk menghasilkan penyajian audio visual penuh.

Multimedia mempunyai peranan yang sangat penting karena saat ini multimedia dijadikan salah satu alat untuk bersaing di era globalisasi ini. Di samping itu pada abad 21 ini multimedia akan menjadi ketrampilan dasar yang sama pentingnya dengan ketrampilan membaca.

b. Tipe E-Learning

Animasi adalah memberi arti "menghidupkan" suatu benda atau obyek yang seolah-olah bergerak hidup sehingga dapat dinikmati dan dirasakan, adegan dalam menggerakkan wayang dalam seni wayang kulit merupakan cikal bakal animasi sehingga animasi modern merupakan salah satu unsur penunjang yang sangat penting dalam memproduksi sebuah aplikasi multimedia. Prinsip dasar animasi adalah menjalankan gambar-gambar yang terlihat frame per frame secara berangkaian dan 
hampir bersamaan, sehingga terlihat seolah gambar tersebut bergerak.

c. Metode Pengembangan Aplikasi

Metodologi merupakan suatu formula dalam penerapan penelitian dimana dalam melakukan penelitian tersebut terdapat langkah-langkah dan juga hasil penelitian. Sedangkan metodologi penelitian dalam ilmu komputer/sistem informasi/teknologi informasi merupakan "langkahlangkah/tahapan perencanaan dengan bantuan beberapa metode, teknik, alat (tools) dan dokumentasi dengan tujuan untuk membantu peneliti dalam meminimalkan resiko kegagalan dan menekankan pada proses/sasaran penelitian di bidang komputer.

Metodologi yang digunakan oleh penulis dalam melakukan penelitian ini adalah RUP (Rational Unified Process). Rational Unified Process merupakan suatu metode rekayasa perangkat lunak yang dikembangkan dengan cara mengumpulkan berbagai best practises yang terdapat dalam industri pengembangan perangkat lunak. Dengan langkah-langkah sebagai berikut:

1) Perencanaan

2) Analisis

3) Perancangan

4) Memulai Proses Coding

Pada tahap perancangan Aplikasi Panduan Akademik ini, dibangun menggunakan UML (Unified Modelling Language). UML adalah bahasa standar yang digunakan untuk menjelaskan dan memvisualisasikan rancangan proses analisis dan desain berorientasi objek.

d. Perancangan Use Case Diagram

Use Case Diagram mendeskripsikan sistem/aplikasi, lingkungan dan relasi antara sistem/aplikasi dengan lingkungannya. Dalam aplikasi yang dibuat, user memiliki beberapa perlakuan umum yang dapat dilakukan.

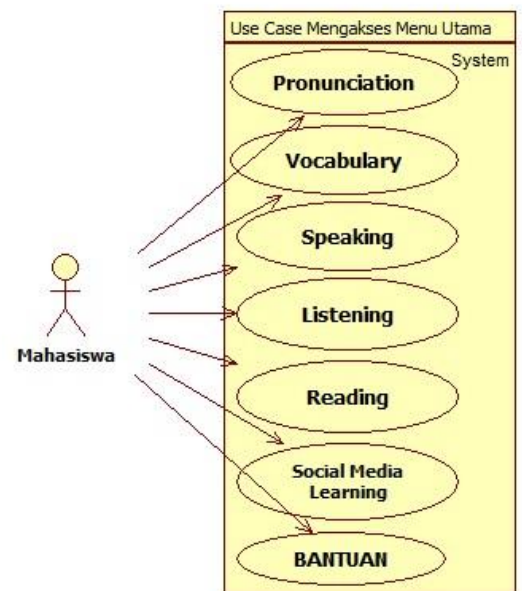

Gambar 1. Gambar use case diagram aplikasi user

\section{e. Perancangan Activity Diagram}

Activity Diagram merupakan gambaran aliran kejadian suatu aplikasi.

Pada activity diagram ini menggambarkan proses yang berjalan di sistem yang dilakukan oleh pengguna dari awal membuka aplikasi sampai menutup aplikasi.

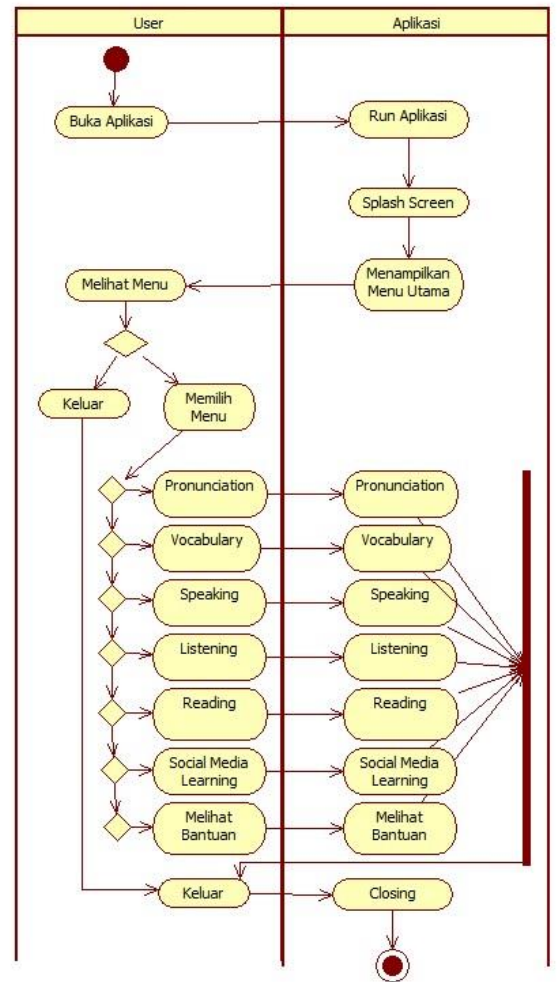

Gambar 2. Gambar activity diagram aplikasi user 


\section{HASIL DAN PEMBAHASAN}

a. Hasil

Dalam tahapan ini, bertujuan untuk mengembangkan dan menggali sebuah media learning bahasa inggris yang menarik dan interaktif sehingga mudah cepat dipahami oleh para mahasiswa.

Masalah yang dihadapi adalah: "Bagaimana Merancang dan Mengimplementasikan media learning yang efektif, menarik dan interaktif E Learning berbasis mobile learning untuk mahasiswa".
Pemecahan masalah: Untuk mengatasi hal tersebut kami mencoba membuat sebuah aplikasi mobile learning dengan menggunakan metode Synchronous and Asynchronous berbasis mobile learning dimulai dengan beberapa langkah-langkah yang praktis dalam upaya membuat media learning yang sederhana dan menarik, yaitu mulai dari pembuatan rancangan aplikasi, pengumpulan data materi learning, pengeditan, sampai pada proses finishing.

Tabel 1. Tabel Hasil Perbandingan

\begin{tabular}{|l|l|l|}
\hline No & \multicolumn{1}{|c|}{ Jenis Perangkat } & \multicolumn{1}{c|}{ Hasil Pengujian } \\
\hline 1 & $\begin{array}{l}\text { PC / Desktop / Notebook / } \\
\text { Laptop }\end{array}$ & $\begin{array}{l}\text { Aplikasi dapat berjalan dengan baik dan lancar } \\
\text { namun dikarenakan layar di notebook tidak begitu } \\
\text { lebar maka logo footer uniku dalam aplikasi hanya } \\
\text { sebagian terlihat }\end{array}$ \\
\hline 2 & Smartphone / Tab & $\begin{array}{l}\text { Aplikasilearning di perangkat smartphone dapat } \\
\text { dijalankan dengan baik. }\end{array}$ \\
\hline
\end{tabular}

Aplikasi Media Learning dengan menggunakan metode Synchronous and Asynchronous berbasisMobile ini dapat berjalan baik pada smartphone yang menggunakan sistem operasi Android di smartphone android.

\section{b. Pembahasan}

Tampilan Tampilan menu intro dibuat dengan tujuan untuk memberikan sebuah gambaran sebelum masuk ke dalam menu utama. Proses pembuatan halaman intro dimulai dengan screen intro animation.

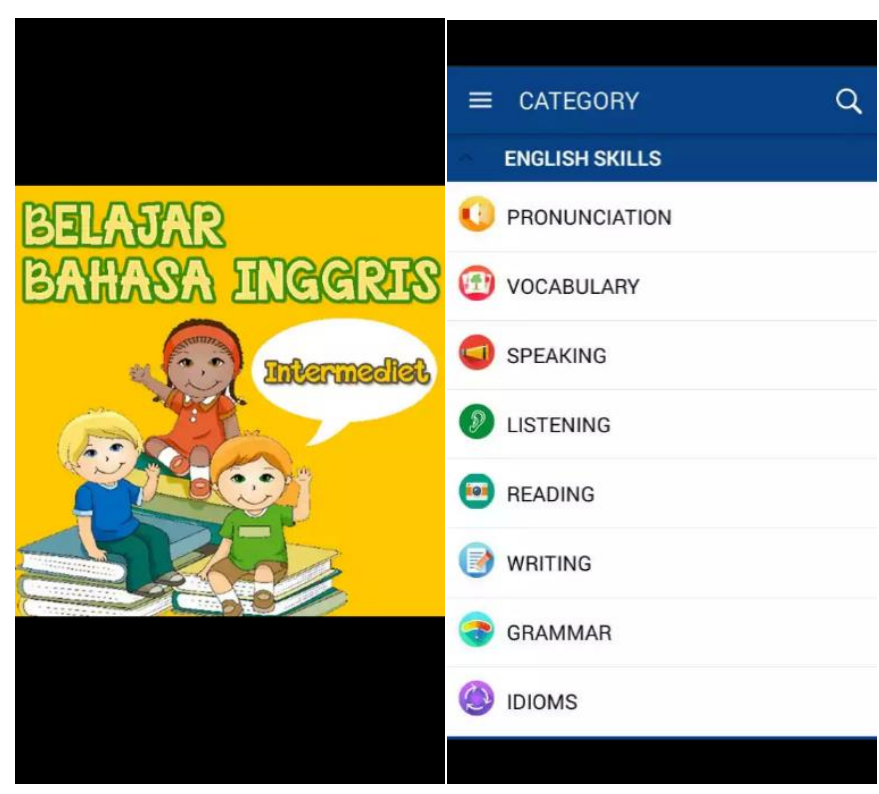

Jurnal Buffer Informatika, Volume 3 Nomor 1, ISSN 2527-4856 
(a)

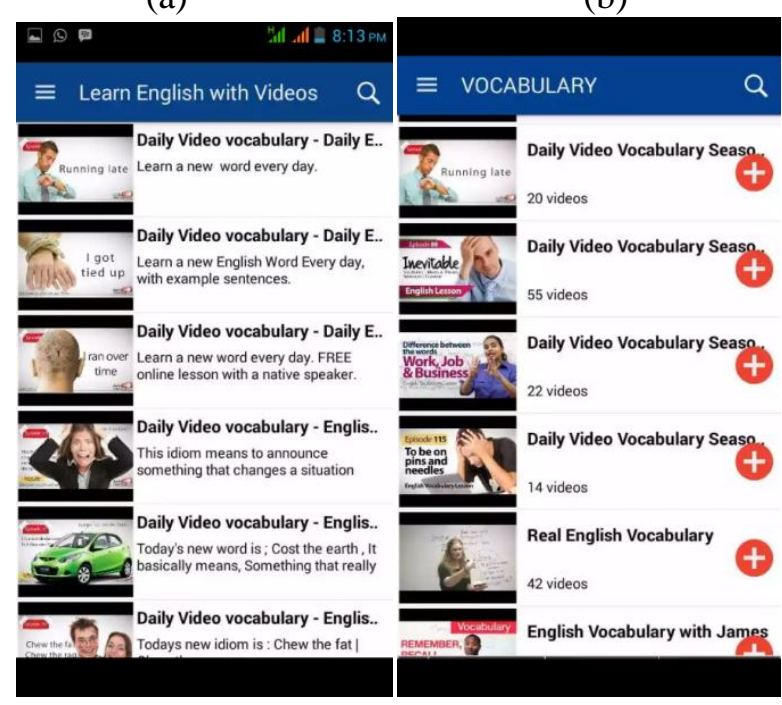

(c)

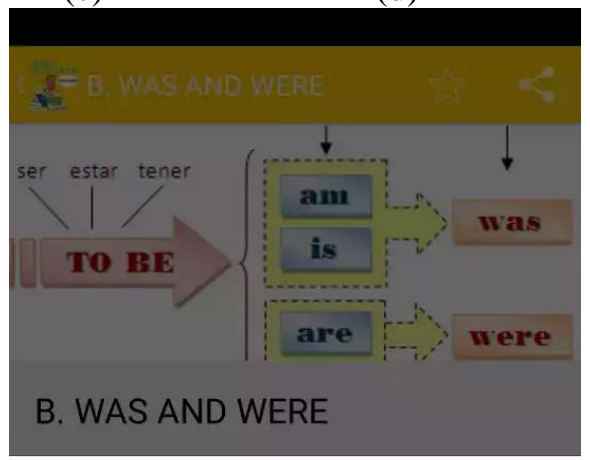

Share via

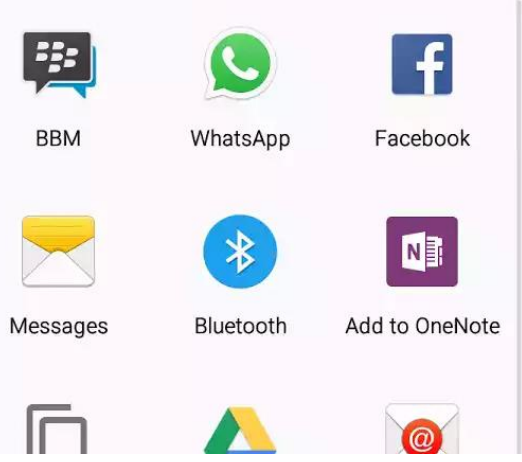

(e)

Gambar 3. Tampilan Aplikasi

Tampilan menu utama akan muncul secara otomatis setelah melewati halaman intro. Di dalam halaman menu utama inilah fasilitas utama/fitur utama dari aplikasi Media Learning dapat dipilih. Terdapat delapan pilihan yang dapat digunakan oleh Mahasiswa. Pilihan yang dapat diakses adalah
Pronunciation, Vocabulary, Speaking, Listening, Reading, Writing, Grammar.

Di dalam menu utama terdapat sub menu Learn English with Videos, jika calon mahasiswa menekan tombol sub menu Learn English with Videos, maka otomatis akan masuk ke halaman Panduan pembelajaran 
melalui interaktif learning melalui Video Bahasa Inggris.

Di dalam menu utama terdapat sub menu Vocabulary jika calon mahasiswa menekan tombol sub menu Vocabulary, maka otomatis akan masuk ke halaman Vocabulary. Isi dari tampilan halaman ini adalah berisi mengenai pembelajaran vocabulary.

Di dalam menu utama terdapat sub menu Social Media Learning English, jika mahasiswa menekan tombol pada sub menu Social Media Learning English, maka otomatis akan masuk ke halaman pembelajaran Bahasa Inggris menggunakan fasilitas Social Media seperti Whatsup, Email, Facebook, dan Blackberry Messanger.

\section{KESIMPULAN}

Adapun kesimpulan yang didapat dalam penulisan hasil penelitian ini adalah:

a. Berhasil dibuatnya sebuah aplikasi media learning bahasa inggris dengan metode Synchronous and Asynchronous sebagai media pembelajaran bagi mahasiswa di Universitas Kuningan yang berbasis mobile learning yang menarik dan interaktif.

b. Aplikasi media learning ini dapat membantu mahasiswa dalam memahami pembelajaran bahasa inggris di Universitas Kuningan.

c. Untuk membangun sebuah aplikasi media learning berbasis mobile ini menggunakan tools software android studio.

d. Pembelajaran bahasa inggris melalui aplikasi media learning menggunakan metode Asynchronous, memiliki kelebihan yaitu konten yang berdiri sendiri, bahan pembelajaran tersedia 24 jam, hanya membutuhkan materi yang diperlukan.

e. Pembelajaran bahasa inggris melalui aplikasi media learning menggunakan metode Synchronous, memiliki beberapa kendala yaitu konten yang ada membutuhkan instruktur yang jelas, instruktur tersedia ketika mahasiswa juga memiliki waktu yang tersedia, kurangnya motivasi belajar mahasiswa, namun keunggulannya Instruktur dapat mengubah konten secara real time.

f. Untuk dapat menjalankan aplikasi panduan akademik di smartphone harus smartphone yang menggunakan OS Android .

\section{SARAN}

Sesuai dengan permasalahan yang ada dan setelah pembuatan media learning ini selesai, maka diberikan beberapa saran yang dapat digunakan dalam pengembangan progam di masa mendatang, antara lain:

a. Aplikasi media learning ini perlu dikembangkan menjadi aplikasi tersendiri yang berbasis mobile supaya memudahkan dalam penggunaan aplikasi.

b. Dibutuhkan kerjasama, tanya jawab dengan pihak-pihak yang terkait dengan proses perubahan dan update materi Bahasa Inggris.

c. Perlu adanya penambahan informasi dan menu yang lebih beragam lagi.

\section{DAFTAR PUSTAKA}

[1] Mulyadi, S. T., 2010, Membuat Aplikasi Untuk Android. Multimedia CenterPublishing. Yogyakarta.

[2] Safaat, Nazrudin. 2011. Android Pemograman Aplikasi Mobile Smartphone Dan Tablet PC Berbasis Android. Informatika, Bandung,

[3] M. Suyanto, 2004. Analisis dan Desain Aplikasi Multimedia Untuk Pemasaran. Yogyakarta : Andi Offset.

[4] Prof. Jogiyanto HM., Ph.D. 2008. Metodologi Penelitian Sistem Informasi.

[5] Zainal A,. Hasibuan, Ph.D, 2007. Mettodologi Penelitian Pada Bidang Ilmu Komputer dan Teknologi Informasi, Fakultas Ilmu Komputer - UI Referensi tambahan. 